\title{
THE KNOWLEDGE SOCIETY AND HIGH PERFORMANCE WORKPLACE SYSTEMS: ENHANCING 'WORKER VOICE'
}

\author{
Bill Cochrane \\ Michael Law \\ Gemma Piercy
}

\author{
Centre for Labour and Trade Union Studies \\ Department of Sociology and Social Policy \\ University of Waikato
}

\begin{abstract}
This paper focuses on an aspect of the 'Future of Work'. The introduction of high performance workplace systems (hpws) is, in general terms, consistent with the broad thrust of the 'knowledge society' debate. The central thesis holds that the introduction of hpws has the potential to enhance 'worker voice, 'especially in the context of a 'third way' political environment that fosters a more tripartite approach to industrial relations. The paper draws on several pieces of research, each of which has its own methodological approach. The discussion of the 'knowledge society' debate and the 'third way' political context draws on policy analyses undertaken by Law and Piercy. The body of the paper is based on a survey by Law of union members engaged in a hpws in a large NZ dairy factory. That research involved focus groups and a postal survey. Qualitative (write-in) responses were further analysed using a dynamic coding system developed by Law. The findings are consistent with the (US) work of Black and Lynch. With some qualifications, the introduction of hpws has enhanced worker participation. Active union involvement was a positive factor. For a proportion of union members, the introduction of hpws has had positive off-site effects.
\end{abstract}

\section{Introduction and Purpose}

This paper focuses on an aspect of the 'future of work:' skill development and high performance workplace (manufacturing) systems (hpws) (Appelbaum, Bailey, Berg, \& Kalleberg 2000; Black \& Lynch 2001, 2004; Lloyd \& Payne 2002; Voos \& Kim 2001) in a 'third way' context (Chaterjee and others 1999; Piercy 2003a; Stalker 2000). The paper is written from a labour studies perspective that places an emphasis on an inherently democratic notion we call 'worker voice;' that is, the active participation of working people in decision making in their employment, in the community, and in broader economic and social life. In our use, this notion refers not only to the collective expression of 'worker voice' through union representation but also the 'voices' of particular groups of workers such as women, Maori, and ethnic workers.

The introduction of hpws is, in general terms, consistent with the broad thrust of more optimistic views of the potential of the 'knowledge society/economy': Tony Blair's (2000) vision of "better growth, better employment an social cohesion." But in Britain, as elsewhere, the 'knowledge society/economy' is not short of 'critics' and 'sceptics' (Lloyd \& Payne, 2002). A problem with such optimism, criticism, and scepticism, however, is that each is often so grounded in specific national conditions that it is difficult to disentangle the different elements that come together in a particular point of view, let alone apply them in a different national context.
The purpose of this exploratory paper is to offer a New Zealand grounded examination of aspects of skill development and hpws in the context of a 'third way' political environment that fosters a more tripartite approach to industrial relations. Almost by definition, this paper is concerned not with breathtaking visions, sweeping claims, and radical social change but rather with practical unionism in circumstances "not of unions and workers own choosing.' In other words, we are interested in the success or otherwise of union-associated initiatives that reflect modest aspirations and a limited sense of possibility in what at best could be described as a qualified, post-neoliberal, political environment.

Our analysis is premised on a quite critical assumption: that the election of a Labour-led Government in 1999 marked a qualitative shift in economic and social policy. Further, we hold that the broad direction of government policy can be described as 'third way' in the loose sense that the term has been employed by writers such as Anthony Giddens (1998; 2000). Indeed, although she seldom employs the term herself, Helen Clark (see 2002), especially when on Giddens' turf, has identified her government with a 'third way approach.' In our view, two policy areas where the Giddens and others influenced, third way prescription is being applied are skill development (education and industry training) (see Piercy 2003a) and industrial relations (see McQueen 2003).

\section{Organisation and Research Approach}

The remainder of the paper is organised into two sections into which is incorporated a measure of theoretical material. These sections build on two sets of research, 
each of which has its own methodological approach. In the first we discuss aspects of the third way politics, the knowledge society/economy debate, and the union movement's strategic approach, substantially in a New Zealand context. This discussion draws on policy analyses undertaken by Law and Piercy over some time (eg Law 1994a, 1994b, 1996a, 1996b, 1998a, 1999, 2001, 2003a, 2003b, 2004; Law \& Piercy 1999, 2000a, 2000b, 2000c; Piercy 1999, 2003a, 2003b). The second section is concerned with hpws. It opens with a brief overview of selected literature, with an emphasis on those aspects that might be helpful in the New Zealand context. This is followed by a case study: union members' views about the implementation of "Manufacturing Excellence", a hpws, at Fonterra's Whareroa (Hawera) factory. These views are taken from focus groups and a postal survey of Dairyworkers' Union members (see Law and Cochrane, 2004). Qualitative (write-in) responses were analysed using a dynamic coding system developed by the principal researcher. It is also clear to us that while we do not make explicit reference to it, the analysis presented in this paper has been influenced by the politics as well as the subject matter of our most recent work (Cochrane, Law, and Piercy 2004a, 2004b, 2004c).

\section{The Third Way, The Knowledge Society, and Union Strategies}

\section{Notes on the Third Way}

The "third way" is an untidy term: a label that has been pinned to political platforms in different countries that have attempted to reconcile the traditional aims of socialism and/or social democracy with the needs of an increasingly globalised, capitalist economy. The Labourled government's third way has been primarily derived from Britain, principally the application of Giddens' $(1995,1998,2000)$ ideas, although it is also possible to detect the influence of former US Secretary of Labour, Robert Reich. Giddens presents his view of the "third way" - which is quite different from the longer established, Scandinavian concept - as a "new" model, a framework of thinking and policy making that seeks to adapt social democratic ideas to a world that has changed fundamentally. He claims that it attempts to transcend both social democracy and neo-liberalism in order to form a new pathway

Giddens (1998; Eichbaum 1999) focuses on five key clements of change:

- the impact of globalisation;

- the rise of individualism;

- the increasing lack of clarity between what is "left" and "right":

- the role of political agency in an economically /socially altered world; and

- the need to pursue sustainable means of dealing with ecological problems.
Throughout these five elements run themes that shape the role of the State, point to a type of partnership model, and encourage collaboration and cooperation between the social partners. Giddens argues that public policy has to shift away from the re-distribution of wealth to wealth creation. This, he claims, will answer some of the social problems caused by the deregulation of markets and threats to social cohesion. According to Eichbaum (1999), in a New Zealand volume that explored the potential of third way politics (Chatterjee and others 1999), a method Giddens advocates to address the threats to social cohesion and the more damaging effects of the market is "a supply side agenda that seeks to alleviate inequality of outcomes by means of equality of access" (p.48). Thus, while the role of the State is still to court capitalism in order to encourage wealth creation, as it was under a neo-liberal regime, it also has to seek to right the wrongs of the market by pursuing public policy that facilitates access to the labour market (Eichbaum 1999).

It follows that industry training is a cornerstone of policies that seek to promote and create social cohesion by facilitating greater access to the labour market. In Eichbaum's words: "The focus is largely on supply-side changes, with the investment in "human capital" elevated to the primary policy objective" (p.54).

The volume of essays by Chatterjee and others (1999) was, of course, an important bridge from the policies of the 1990 s to those of the 2000 s, especially given that union-associated authors such as Eichbaum and Peter Harris took up senior policy positions with the new government and another, Peter Conway, with the Council of Trade Unions (CTU). But it would be a mistake to infer from the book's title that the thinking contained within it represented a major, paradigmatic shift on the part of the authors. More accurately, the authors drew on what might be called "evolving continuities" in union and independent left thinking in order to engage critically the third way literature. Thus in their introduction, Eichbaum and Harris (1999) describe the third way as a "permissive brand" that "at its most basic ... suggests an alternative to the polar option of laissez-faire capitalism on the one hand and statistic regulation on the other" (p.14)

Having said that, there are many points in the book where essay authors advocate a much more active role for the state than do, say, Giddens and Reich. In an era when the stability of small economies is threatened by "footloose finance" (Harris 1999, p.22) a "new way ... recognises the new realities of amore global system of finance and trade while pushing the remaining discretions of sovereign nations to their limits" (p.26) (our emphasis). And later, "Governments are not hamstrung," claim Harris and Eichbaum (1999 p.224), "there is both a need and the scope for innovation". A "key element", they hold, is that the government "accepts new responsibilities and finds better ways of delivering through dynamic economic and social partnerships." The powerful rationale for what might be called a "new state (or labour) experiment" (see Reeves 1902; Sinclair 1988) taps the same, very deep strain of thinking that has characterised centre-left politics in New Zealand for well over a 
century: the vulnerability of a small, export dependent economy.

Harris and Eichbaum (1999) identify the lack of a coherent industry policy as "the gaping hole in the fully deregulated market economy" (p.228) and advocate a rethink of labour market regulation:

This is not just about workers' rights and obligations, or about the role of unions. Important issues are integration of labour market and industry policy, making a wages policy an effective and democratic part of macroeconomic management, improving education about rights and enforcement of them, and, of course, reviewing the design of the statutory safety net (p.230).

The inclusion of "democratic" in the above is not, we suggest, unimportant. Rather it is consistent with another powerful theme (see an earlier quotation): the need for "dynamic economic and social partnerships". The authors, in keeping with a Giddens' perspective, view unions not simply as bargaining agents, but also as a very active component of a revitalised civil society. As Eichbaum (1999, p.57) observes earlier in the book:

The renewal of civil society, through the establishment of democratic institutions and the kind of institutional "inbuilding" suggested by the stakeholder model, is central to the new economics as well as the new politics. These elements of the Third Way programme stand in stark contrast to the neoliberal orthodoxy...

\section{Notes On The Knowledge Society/Economy}

It is in the context of the above that we now refocus on education and industry training. Although skill development is a major feature of the third way's emphasis on supply-side policies, industry training had been a cornerstone of both the union movement's and the Labour Party's industry policies for a decade or so before the latter's election to government in 1999. The full story of the union movement's embrace of industry training and the influence of Australian unions is presented very comprehensively in Piercy's (1999) MSocSc thesis as well as in other papers (eg Law \& Piercy 2000b). Significantly, Eichbaum, then employed by the Engineers' Union (EMPU) was a key player. As early as 1993, in its Building Better Skills series of booklets, the CTU highlighted, when it was a lot less fashionable than it is now, core elements of the economic case for an inclusive, co-operative approach to industry development and training (see also NZCTU 1992a, 1992b, 1993a, 1993b; Doyle 1999).

The Labour Party's (1999) manifesto document, $2 I^{s t}$ Century Skills: Building Skills for Jobs and Growth, represents a mix of continuities and a degree of discontinuity. The continuities are to be found in its retention of the previous 1984-90 Labour Government's initiatives and the influence of the CTU's documents. These continuities are reflected in the policy document's affirmation of the role of education and training in contributing to international competitiveness; its reiteration of the notion of pathways to higher qualifications and greater skills; and its re-emphasis of the importance of a need for clarity in the transition from school into industry. The discontinuity pivots around the shift in Labour's faith in a market model of organisation and delivery. In the Learning for Life documents of the late 1980s, the then Labour Government had subscribed to a co-ordinated approach to industry training, although in practice its policies placed considerable reliance on a market model to organise and deliver that training. After nine years in opposition, Labour (with considerable assistance from unions) had sharpened its understanding of the limitations of the facilitative, voluntarist model and was more inclined to a legislative, semi-regulatory approach coupled with a more pronounced, "third way" notion of partnership.

Labour was critical of the National Government's failure to establish the pathways and links between employment and training that were necessary for economic growth. It held that the abolition of apprenticeship and the voluntary approach had created a system that was at best "hit-andmiss". Labour advocated a co-ordinated approach that would encourage all workers to up-skill and to retrain throughout their working lives. The central theme threaded through the policy document was the view that education and employment/industry/economy had to be brought together.

By 1999, Labour in government, was well poised to pick up and amend the "knowledge society/economy" discourse. Its election also paved the way for the reincorporation of unions into industry training. As noted above, the new government was more inclined to a legislative, semi-regulatory approach and a notion of partnership (Law 2003; Piercy 2003) that provided a structured link between unions and the knowledge society. The Employment Relations Act re-established the basis for a return to some degree of tripartism; the provision of Employment Relations Education (ERE) addressed issues of capacity (Street \& Law 1999; Law $2003 \mathrm{~b})$. Health and Safety legislation also strengthened unions' workplace presence. In education and training, the term "tripartite" came back into favour. This return to a three-way partnership in industry training was not surprising, given the third way emphasis on the role of education and training in promoting a "social justice" notion of social cohesion (Eichbaum 1999; Forrester 2001).

The stakeholder model was further underpinned by the four reports of the Tertiary Education Advisory Commission (TEAC). These led to the creation of Tertiary Education Commission (TEC) and the Tertiary Education Strategy (TES), a five-year plan for postcompulsory education and training. The TES incorporates and reflects:

- Key assumptions of human capital theory, particularly those which were developed in response to the "need" to be internationally competitive;

- The third way assumption that access to education will lead to increased employment opportunities for the wider society which in turn will lead to greater social cohesion; 
- The findings and key recommendations of the industry training review; and

- The essence of the four TEAC reports, in particular the final one, Shaping the Funding Framework (TEAC 2001).

The purpose of the TES is: to outline how, by making "best use of one's resources", tertiary education can make its contribution to the development of the Government's national goals. Through the TEC, it enables the government to steer the PCET system through six strategies:

- $\quad$ Strengthen system capability and quality;

- Contribute to the achievement of Maori development aspirations;

- Raise foundation skills so that all people can participate in our Knowledge Society;

- Develop the Skills New Zealanders need for our Knowledge Society;

- Educate for Pacific Peoples' development and success:

- Strengthen research, knowledge creation and uptake for our Knowledge Society.

The emphasis on the needs of the economy and skill confirms that the centrality of the workplace as both the focus and a site of learning, with industry training organization (ITOs) playing a central role in its organisation and co-ordination. Unions implicitly also have a key role to play through: their presence at the workplace: their ability to win worker support for a "learning culture"; and their proscribe membership, as a result of a legislative amendment, on the boards of ITOs. Of course all of this raises a number of questions about capacity, which the CTU, with government assistance, is addressing (see Law 2004).

\section{Notes On Union Strategies}

As noted above, by the early 1990s the Engineers' Union and the CTU had identified industry training as a point of strategic leverage. A position that accorded with Wolfgang Streeck's (1992) sense of union possibilities, even though few in this country were familiar with that work (see Law \& Piercy 2000a). At one level, Labour's election in 1999 ended almost a decade of systematic attempts to exclude unions from industry training. The new government wanted an "integrated skills and employment strategy" (Maharey 2001, p.2). Following the industry training review, the government opened up the possibility for unions to have a presence on ITO boards, but with a degree of ambiguity. The use of the words "employee representation" in legislative amendments rather than "union" has resulted in some tension ( $\sec$ Conway 2003; NZCTU 2003).
Parallel with the establishment of the TEC, it was decided to retain "Skill New Zealand" as a "brand" to promote workplace training: "a tripartite initiative to promote quality, relevant and accessible workplace learning" (BusinessNZ 2002, p.1). This initiative confirms that the principal employer body now accepts that unions are relevant and appropriate stakeholders in industry training. ITO profiles, necessary for TEC funding, must demonstrate that they are "developing arrangements for the collective representation of employees in the governance of the organization." in order to gain approval (Government cited in NZCTU 2003). Two booklets have been developed in conjunction with stake holders in order to provide employers and employees with a guide to industry training.

As noted earlier, the capacity of unions to participate effectively as social partners, including in industry training, remains a issue. In early 1999, the CTU asked Maryan Street and Michael Law (1999) to develop a policy paper on the restoration of state assisted trade union education and a legislative entitlement to paid educational leave. The need to rebuild union capacity building was a central plank in that paper's case for ERE. Once the ERA restored basic union education rights, the CTU sought state funding for more strategic projects. One, the "Industry Training Union Capacity Building Project", sought to:

- "up-skill unions to ensure effective participation in the governance of ITOs;

- increase union involvement in industry training;

- inform unions about tertiary education reforms; and

- enhance union relationships with other stakeholders in the tertiary sector" (Beaumont 2003).

At the first seminar, Peter Conway sketched the union movement's strategic framework. He emphasised the CTU view that unions, as workers' representative organisations, had a right to be actively involved as full partners in industry training. However for this to be effective, union representatives had to develop an understanding of the "political economy of skill and skill development" (quoted in Law 2004 from notes). Central to this was the need for a solid understanding of the policy debates around tertiary education. Conway developed these themes at a later seminar where he presented the CTU's overall strategic framework in more detail. The main features are:

sustainable development;

growth and innovation;

economic transformation;

inclusive economy; and

a social development approach.

Unions accept that for the economy to deliver reasonable living standards, industry training and skill development 
has to be linked to economic development, including regional economic development. This requires union involvement in the creation and implementation of industry strategies. Using the notion of "organising plus", the CTU also holds that industry training has to be linked to broader workplace issues such as work-life balance, health and safety, and worker involvement. This extends beyond the workplace to issues such as the strengthening of civil society, enhancing general educational opportunities, social development, and an improved social wage. These central themes, which are consistent with much of the Chatterjee and others (1999) volume, were explored, argued, and developed by other contributors and by participants over the course of the main seminar series and during two additional, abbreviated series.

\section{Unions and High Performance Workplace Systems: A Case Study}

\section{Background}

In the late 1980 s and early 1990 s, many New Zealand unions bought into the workplace reform campaign which was very actively promoted by the Engineers' Union, the CTU, and the Trade Union Education Authority (TUEA). Although in one sense momentum peaked with the holding of the Workplace New Zealand Conference in September 1992, the enactment of the Employment Contracts Act in 1991 and the disestablishment by way of statutory repeal of TUEA a year or so later were fairly ominous signs that this particular initiative was unlikely to survive the neoliberal onslaught. Thus by the time Reform at work (Perry, Davidson, and Hill 1995) was published, workplace reform's moment had past. A little later, in a critical analysis, Paul Harris and David Neilson (1996) noted the very limited involvement of unions at the workplace in the case studies presented to the 1992 conference.

One of the unions that throughout the 1990s retained quite a strong commitment to the general principles of workplace reform was the New Zealand Dairyworkers' Union (DWU). As the early 1990s case study is written up in Perry, Davidson, and Hill (1995 pp.98-118), there is no need to recount more than the briefest details here. Following a major industrial confrontation in the late 1980s, the DWU and the industry, with the help of the CTU, sought to follow a more cooperative path. Under a Memorandum of Understanding (MoU), an industry approach to skill development and job redesign was introduced.

Union and industry employer representatives visited all sites to promote the strategy. However when Jocelyn Gibson (1994) interviewed workers on four sites and key officials from both sides in late 1992 and 1993, she found mounting evidence that there was insufficient trust within the industry to make the strategy work. She concluded: "There is evidence to suggest that the first steps towards a high trust dynamic at a national level were taken, but it seems that the new trust dynamic was unsustainable" (pp.49-50). About the same time (1993), Michael Law (1994b, 1998b) undertook a postal survey of the union's membership. It included a series of questions about the $\mathrm{MoU}$ and its implementation. The findings were not encouraging. Fewer than half the union members on the MoU sites supported the strategy, although only a very small minority $(3.9 \%)$ were hostile to it. Further, while members were very supportive of efforts to introduce skill-based pay, negative comments about the MoU were often linked to doubts about employers' motives and intentions. The study also unearthed considerable reservations about the effectiveness of the worksite consultative process that had been established under the MoU. Eventually, the MoU initiative fell over, but that did not dull the union's interest in workplace systems that might offer members the opportunity to develop their skills and to have greater involvement in and control over their work.

\section{High Performance Workplace Systems: Some Notes On The Literature}

The CTU's broad approach to economic development as outlined in its 2003 publication, Unions Innovation and Sustainable Development (2002), advocates worker involvement. In his Foreword, CTU president, Ross Wilson, states:

\footnotetext{
"We argue strongly that 'industry' is not just 'business' Workers in their industries have experience, knowledge, insights and innovative ideas on how to improve productivity, create investment opportunities, and improve workplace relations" (p.3).
}

The difficulty, of course, is finding appropriate mechanisms to facilitate such participation. With the demise in Australia of the cooperative framework provided by the Accord, Europe provides the best insights into the success or otherwise of a social partnership strategy on the part of unions. Informed opinion varies considerable, depending on the perspective of the authors. However from a purely economic point of view, Asteriou and Monastiriotis's (2004) longitudinal study concludes that at the macro-economic level both the "long- and short-run effects (of the relationship between unionisation and productivity) are positive and statistically significant" (p.44).

In a comprehensive volume, Appelbaum, Bailey, Berg and Kalleberg (2000) examine the impact of workplace practices that incorporate worker involvement in the organization of work, so called high performance work systems (hpw), across three industries in the United States: apparel, steel, and medical-instrument manufacturing. They report that in workplaces that implemented such systems productivity, the quality of production and customer service, worker levels of organizational commitment, job satisfaction and wages were all higher than in comparable firms that had not implemented such systems. Thus the adoption of hpws, they argue, is able to deliver both to the employer, through productivity, profitability and competitiveness, and to the worker, through high wages and quality jobs. 
Black and Lynch $(2001 ; 2004)$, in their analysis of the productivity effects of the implementation of high performance work systems, information technology, and human capital investments, also indicate that while technological innovation can deliver gains in productivity, what matters most in terms of productivity is the extent to which workers are given a "voice" in the process of workplace innovation. Importantly for the trade union movement, they find that the greatest improvements in workplace productivity occur in unionised workplaces that have adopted practices that foster worker involvement and participation.

Similarly Business Decisions (1999) conducted on behalf of the European Commission a review of a large number of case and academic studies. It identified the need to involve workers in the process of change, and to work in partnership with them, as critical to the effective implementation of change in the workplace. Farris and Tohyama (2002) discuss the role of worker voice in the introduction of various varieties of lean production. Lean production has frequently been criticised (see for instance Parker and Slaughter $(1988,1994)$ for achieving increases in productivity and product quality through increased worker effort and stress, and reduced worker health and safety. Farris and Tohyama (2002) find that this "mean" side of lean production can be mitigated by the presence of worker voice mechanisms that insure the equitable sharing of gains, thus legitimating the authority of management, and leading workers to willing cooperate with management to enhance productive efficiency.

Also of some immediate relevance is a British study (Bacon and Blyton 2003) which explored employee perception of "who gains and who loses" with respect to the impact of teamwork on skills. The study focussed on a unionised steel plant that had introduced teamwork some five years earlier. Bacon and Blyton report that overall team working was "associated with feelings of increased skill, variety and influence over quality" (p.26). But the authors also report that the results "reveal a differential experience between those with different occupational backgrounds and different hierarchical levels" (p.26), Bauer (2004), using data from the European Survey on Working Conditions (ESWC), examined the effect of hpws on workers' job satisfaction history and found that the higher involvement of workers under hpws was positively associated with higher levels of job satisfaction. The increased levels of job satisfaction experienced under hpws arose predominantly from increased autonomy over how tasks were performed along with the increased levels of communications with co-workers.

\section{The Dairy Industry Study}

In the late 1990s, on the initiative of the Dairyworkers' Union, the union and the then Kiwi Dairy Cooperative agreed to introduce a hpws at the Whareroa (Hawera) site. The programme, known commercially as "TRACC", is owned and has been developed by a South African company, Competitive Capabilities. It should be noted that there is nothing particularly remarkable about TRACC. The programme has evolved from the company's accumulated expertise and experience since 1985 in "world class manufacturing and best practice." On the surface, it looks like just another workplace system based on semi-autonomous team that incorporates best practice benchmarking, visual mapping, the development of skills matrices, and the like. What seems to give it something of a distinctive edge is the emphasis placed on stakeholder involvement. The consultants responsible for the Whareroa project, Australian Workplace Solutions, prefer this involvement to be through unions and it was this factor that first appealed to the DWU. Within Fonterra, the programme is now known as "Manufacturing Excellence" (ME) (Parkin 2004).

In 2002, the DWU commissioned Michael Law to evaluate, from the perspective of union members, the ME/TRACC programme that had been progressively implemented at Whareroa. The study was conducted in two phases: focus groups and a postal survey. Because of the nature of work in the industry, especially shift work and the substantially off-site dimension of milk collection, the postal survey has been found in the past (Law 1994b, 2002) to be a productive way of gathering data from DWU members. A systematic sample was generated from a random base with questionnaires were sent to about $50 \%$ of union members working in departments/sections in which ME had been introduced. The response rate was $54 \%$; this yielded 106 useable questionnaires.

\section{Educational dimension}

ME like other HPWS, involves a considerable amount of training. While such programmes are, in theory, intended for workers with a diverse range of previous educational experiences, there can be a tendency for those with a strong educational background to play a more prominent role.

In the Hawera study, female respondents, many of whom were laboratory workers, were a little better qualified, in terms of highest secondary qualification, than male respondents.

Maori respondents had, however, lower high school qualifications than European/Pakeha. 
Table 1: Highest Secondary School Qualification by Gender (percent within gender only)

\begin{tabular}{|c|c|c|c|}
\hline Highest secondary qualification & Male & Female & Total \\
\hline None & 28.4 & 20.8 & 26.7 \\
\hline NZSC I+ subjects or NC level I & 29.6 & 20.8 & 27.6 \\
\hline NX 6 form cert $1+$ subjects or NC level 2 & 12.3 & 12.5 & 12.4 \\
\hline NZ UE before 1986 in $1+$ subjects & 9.9 & 16.7 & 11.4 \\
\hline NZHSC or HLC & 4.9 & 0.0 & 3.8 \\
\hline UE from NZ bursary & 2.5 & 8.3 & 3.8 \\
\hline A or B bursary, Scholarship or NC level 3 & 3.7 & 4.2 & 3.8 \\
\hline Other NZ secondary qualification & 1.2 & 0.0 & 1.0 \\
\hline Overseas secondary & 2.5 & 16.7 & 5.7 \\
\hline Missing & 4.9 & 0.0 & 3.8 \\
\hline Totals: Percent within Gender & 100.0 & 100.0 & 100.0 \\
\hline
\end{tabular}

\section{Quality Of Teaching/Consultancy}

A number of questions scattered throughout the questionnaire probed how well ME had been implemented, the quality of training and consultancy, and recommendations for improvement. The responses should really be read in the context of the full study, but the examples provided in this paper indicate how such questions can be useful. For example

(Q. 27) How do you rate the overall quality of teaching/training you have received on Manufacturing Excellence courses?

$$
\begin{array}{lc}
\text { Good/very good } & 49.0 \% \\
\text { Average } & 30.2 \% \\
\text { Poor/very poor } & 20.9 \% \\
\text { Valid responses }=96
\end{array}
$$

ME at Hawera relies quite substantially on workplace co-ordinators and trainers selected from the shop floor. The survey confirmed the impressions gained during focus groups that there was strong support for the contribution made by workforce co-ordinators and trainers. Workers respond well to their colleagues as coordinators and trainers.

A good aspect of ME is the involvement of Hawera workers as coordinators and trainers

$$
\begin{array}{ll}
\text { Agree/strongly agree } & 74.2 \% \\
\text { No feelings either way } & 15.5 \% \\
\text { Disagree/strongly disagree } & 10.3 \% \\
\hline \text { Valid responses }=67 &
\end{array}
$$

\section{Other Useful Insights: A Selection}

The following selected insights provide a snapshot of other useful information that is emerging from the study.
Here the emphasis is on responses to questions with an education and training focus.

- The principles of ME aren't much different from other programmes, it's the way they are brought together, implemented, and backed up that makes it work. ( $81.2 \%$ agree/ strongly agree).

- Before any section/department implements ME, as many people as possible should do the five-day course ( $81.0 \%$ agree/ strongly agree)

- The people in my section/department thought the games that we played on the courses were a lot of nonsense. $(46.8 \%$ agree/strongly agree; $24.5 \%$ disagree/strongly disagree).

- Some of the ME modules, like leadership, cover stuff that's done in other programmes. There should be recognition of prior learning $(61.2 \%$ agree/strongly agree; $14.4 \%$ disagree/strongly disagree).

- Management has supported the implementation of the manufacturing excellence program by providing adequate training $(49.0 \%$ agree /strongly agree; $27.2 \%$ disagree/strongly disagree).

\section{Autonomy}

There is a close association between autonomy at the workplace, worker voice, and worker participation. One of the most important claims made about hpws, such as $\mathrm{ME}$, is the opportunity they provide for workers to exercise a degree of control over their workplace. Although the next table is but one of several, it shows that workers had mixed views about autonomy.

There is not as much real worker involvement as everyone claims. When you look closely, most ME teams are dominated by people on the higher levels. Lower level workers aren't really involved.

$$
\begin{array}{ll}
\text { Agree/strongly agree } & 49.5 \% \\
\text { No feelings either way } & 16.2 \%
\end{array}
$$


Disagree/strongly disagree $\quad 34.3 \%$

Valid responses $=99$

\section{Union Involvement}

Previous studies conducted by the CLTUS revealed the value placed on union involvement in industry training. Although, again, the next tables do not tell the whole story, in general they confirm that for a significant proportion of the workforce, union involvement is important.

I wouldn't be too keen on ME if the Dairy Workers Union wasn't actively involved.

$\begin{array}{ll}\text { Agree/strongly agree } & 31.9 \% \\ \text { No feelings either way } & 33.0 \% \\ \text { Disagree/strongly disagree } & 35.1 \% \\ \text { Valid responses }=94 & \end{array}$

In general, do you agree that unions should be involved in promoting HPWS such as ME?

\begin{tabular}{ll} 
Agree/strongly agree & $70.7 \%$ \\
No feelings either way & $17.2 \%$ \\
\hline Disagree/strongly disagree & $12.1 \%$ \\
\hline Valid responses $=99$ &
\end{tabular}

Personal Development And Benefits In The Home And Community

Earlier focus groups had suggested that many workers developed personally as a result of their participation in ME. The study confirmed that initial finding.

I've never done anything like ME before and I have benefited a lol as a person.

$\begin{array}{ll}\text { Agree/strongly agree } & 38.6 \% \\ \text { No feelings either way } & 28.1 \% \\ \text { Disagree/strongly disagree } & 33.3 \% \\ \text { Valid responses }=96 & \end{array}$

The Manufacturing Excellence programme has had a heneficial impact on my life outside of work.
Agree/strongly agree
$22.6 \%$
No feelings either way $\quad 31.2 \%$
Disagree/strongly disagree $\quad 46.3 \%$
Valid responses $=93$

Please outline any benefits that workplace training, including Manufacturing Excellence courses, has had on your life at home.

Thirty three percent $(33 \%)$ of respondents were able to identify some positive impact. For example:

- $5 S$ Programme, general household organisation teamwork, recognition of differing skill levels and individual strengths. Better discussions, more inclusive.

- Awareness of standards and maintaining these in everything outside of work.

- My home and sheds are tidy and clean.

- Gives a better outlook on life in general which makes me happier.

- Hazard ID and pathogen control (housekeeping and hygiene).

- To look at the big picture and take ownership.

- The training has allowed me to take a more positive view on life.

- I have found an area that I excel at. Going to work in the morning is now a pleasure.

- More satisfied leaving work in a safe condition for my fellow team mates.

- $\quad$ More awareness of making things safer and keeping things clean.

- Problem solving.

- $\quad$ More relaxed, see the bigger picture in situations.

- You can organise your way of living better.

- Mainly the safety aspect and its not so much for myself but to my wife and kids.

- I have more tools available to me to deal with interpersonal issues domestically.

- Reminds me to be more vigilant, tolerant, tidier, motivated at home, family, friends.

- More focus on safety, tidiness and hygiene.

\section{Benefits In Terms Of Community Involvement}

Forty-one percent $(41 \%)$ of the respondents who commented identified benefits in terms of community involvement. The main themes were:

Confidence

- Have joined a committee. 
- I can speak in front of a large group more confidently.

Organisational skills and knowledge of how groups work

- Understand organizations better, I'm secretary of a club, more informed of structures and processes involved in an organisation.

- I understand other groups a little bit more now but I don't think you can apply ME everywhere.

- Greater awareness in my involvement with organisations I am involved with. Better goal setting and more achievement based, decision making in teams.

- Relaying of practices to outside groups has enhanced or improved these areas. Others are becoming aware of these practices and are understanding them

- $\quad$ ME has given me a better understanding why things don't progress in other organisations.

- I have a better understanding of participating or chairing effective production meetings.

- I guess now I am learning the broader picture of the business. Meeting new people

- Able to prepare and take my time to prepare more.

- School board of trustees, Deputy Club President - It helped at meetings, and prize givings etc.

- Shown a structured meeting process etc, where all voices are heard.

\section{Summary}

There is nothing particularly profound in the selection of preliminary findings reported here or, for that matter, in the other analyses we have completed thus far. The study provides little evidence of workers gaining significant control over their work, although the findings overall suggest that many believe the workplace to be more pleasant and, most importantly, safer. But the findings do support the general view we have developed over the course of several studies, especially those involving DWU members:

- Workers welcome the chance to take up training opportunities, even when they are not linked to NQF units/qualifications;

- Workers can make effective educators; and

- Many workers can identify off-site (home and community) benefits that result from workplace and, seemingly, work-oriented education.
This study reflects that the relationship between industry training and unions is enduring. It also hints that the knowledge society provides an important opportunity for this relationship to encompass aspects of adult education beyond industry training. It is our intention to undertake further analysis with a view to comparing our findings with overseas studies of unionised workplaces, such as those by Bacon and Blyton (2003) and Black and Lynch (2001, 2004).

\section{Conclusion}

We stated in the Introduction that almost by definition, this paper is concerned not with breathtaking visions, sweeping claims, and radical social change but rather with practical unionism in circumstances 'not of unions and workers own choosing.' In the wake of the neoliberal experience, New Zealand unions, especially in the private sector, are engaged in the long, slow process of re-unionisation and revitalisation. The problem is that the pace of change will not slow in order to accommodate unions' need to rebuild their workplace presence and strengthen their capacity. Thus individual unions and the CTU have to pursue strategies that facilitate organisation while enabling workers and unions to make gains where they can.

On balance, we are of the view that within the framework of New Zealand's unique, 'third way state experiment' and within the context of knowledge society/economy policies, there is a degree of space for 'worker voice.' Further, we are also of the formative opinion that, within limitations, the interconnection between skills development, hpws, and worker voice is positive from a democratic/labour studies perspective. We propose to continue to explore this theme in future research.

\section{References}

Appelbaum, E., Bailey, T., Berg, P. and Kalleberg, A. L. (2000). Manufacturing Advantage: Why HighPerformance Work Systems Pay Off. Ithaca, N.Y: ILR Press.

Asteriou, D. and Monastiriots, V. (2004). What do unions do at the large scale? Macro-Economic evidence from a panel of OECD countries.Journal of Applied Economics, 7(1), $422-440$.

Bacon, N. and Blyton, P. (2003). The Impact of Teamwork on Skills: Employee Perceptions of Who Gains and Who Loses? Human Resource Management Journal, 13(2), 13-29.

Bauer, T.K. (2004). High Performance Workplace Practices and Job Satisfaction: Evidence from Europe. (No. IZA Discussion paper 1265). Bonn: Institute for the Study of Labor

Black, S.E., and Lynch, L.M. (2001). How to Compete: The Impact of Workplace Practices and Information Technology on Productivity. The 
Review of Economics and Statistics, 83, 434 445 .

(2004). What's driving the new economy?: the benefits of workplace innovation. The Economic Journal, 114, F97-F116.

Blair, A. (2000). Speech to the Knowledge 2000: Conference on the knowledge driven economy 7 March, London. Available: (http:dRwww.dti. gov.uk/knowledge2000/blair.htm).

Business Decisions Limited (1999). New Forms of Work Organisation and Productivity: A Study Prepared By'Business Decisions Limited for DGV of the European Commission, Brussells: The European Commission.

Business New Zealand (2002). Tripartite Initiative on Workplace Learning. Wellington: Author.

Chatterjee, S., Conway, P., Dalziel, P., Eichbaum, C., Harris, P., Philpott, B. and Shaw, R. (1999). The New Politics: A Third Way for New Zealand. Palmerston North: Dunmore Press.

Clark, H. (2002, 21 February). Prime Minister's Address to the London School of Economics. [On-line]. Available: http:/www.executive.govt.nz/speech. cfm? speechralph $=37394 \& \mathrm{SR}=1$.

Cochrane, W., Law, M. and Piercy, G. (2004a). Demographic Report on the Trainee Profile of the New Zealand Industry Training Organisation. (Commissioned report for the NZITO) Hamilton: Centre for Labour and Trade Union Studies, University of Waikato (pp.16).

(2004b, 11 June). Skills Forecasting and Industry Training Pathways. Paper presented to the Industry Training Federation Vocational Education Research Conference Forum, Hotel Intercontinental, Wellington.

(2004c). The Food and Beverage Sector: A Trade Union Perspective. (A draft report prepared for the NZCTU). Hamilton: Centre for Labour and Trade Union Studies, University of Waikato.

Conway, P. (July 2003). Collective Employee Representation in ITO Governance Provisions. Presentation at the 2003 Industry Training Federation Conference. Wellington: New Zealand Council of Trade Unions.

Department of Education (1988). Learning for Life: Education and Training Beyond the Age of 15. Wellington: Author.

(1989). Learning for Life Two: Education and Training Beyond the Age of 15: Policy Decisions. Wellington: Author.
Doyle, S. (1999). Workers' organisations and private sector training: The New Zealand Council of Trade Union's strategy for a skilled workforce. Paper to ILO APSDEP Regional Seminar, Chiba, Japan.

Eichbaum, C. (1999). The politics and economics of the Third Way. In Chatterjee, S., Conway, P., Dalziel, P., Eichbaum, C., Harris, P., Philpott, B. and Shaw, R. The New Politics: A Third Way for New Zealand. Palmerston North: Dunmore Press.

Eichbaum, C. and Harris, P. (1999). Why this book? In Chatterjee, S. et al., The New Politics: A Third Way for New Zealand. Palmerston North: Dunmore Press.

Farris, D. and Tohyama, H. (2002). Productive Efficiency and the Lean Production System in Japan and the United States. Economic and Industrial Democracy, 23(4), 529-554

Forrester, K. (2001). Modernised learning: An emerging lifelong agenda by British trade unions? Journal of Workplace Learning, 13(7/8), 318326.

Gibson, J. (1994). Award Restructuring in the New Zealand Dairy Manufacturing Industry. Unpublished MSocSc thesis, University of Waikato, Hamilton.

Giddens, A, (1995). Beyond Left and Right: The Future of Radical Politics. Oxford: Polity Press

(1998). The Third Way. Cambridge: Polity Press

(2000). The Third Way and Its Critics. Cambridge: Polity Press

Harris, P. (1999). Rogernomics, the 'Washington Consensus' and New Zealand economic policy. In S. Chatterjee et al., The New Politics: A Third Way for New Zealand. Palmerston North: Dunmore Press.

Harris, P. and Eichbaum, C. (1999). Towards a postWashington Consensus. In S. Chatterjee et al., The New Politics: A Third Way for New Zealand. Palmerston North: Dunmore Press.

Harris, P.A. and Neilson, D. (1996). Technological determinism and workplace reform: The Mathews debate in New Zealand. Journal of Australian Political Economy 37, 68-93.

Law, M. (1994a). Adult education and working people: A critical reappraisal. In Klenovesk, T. and Olesen. H. (eds), Adult education and the Labour Market (146-183). Ljubljana: Slovenia Adult Education Centre.

(1994b). Membership Survey, NZ Dairy Workers Union: Final Report, Hamilton: Centre for 


\section{Labour and Trade Union Studies, University of} Waikato.

(1996a) Workers' education and training in a new environment. In Benseman, J., Findsen, B. and Scott, M. (eds), The Fourth Sector: Adult and continuing Education in Aotearoa/New Zealand (159-176), Palmerston North: Dunmore Press.

(1996b). Workers' education and training in a new environment. In Benseman, J., Findsen, B. and Scott, M. (eds), The Fourth Sector: Adult and Community Education in Aotearoa/New Zealand (159-176). Palmerston North: Dunmore Press.

(1998a). Market oriented policies and the learning society: The case of New Zealand. In Holford, J., Jarvis, P. and Griffen, C. (eds), International Perspectives on Lifelong Learning (168-179). London: Kogan Page.

(1998b). Mopping up after spilt milk: A survey of union members in the dairy industry. In Harbridge, R., Gadd, C. and Crawford, A. (eds), Current Issues in Industrial Relations: Proceedings of the 12th AIRAANZ Conference (212-220). Wellington: Association of Industrial Relations Academics of Australia and New Zealand.

(2001) Dairy workers and industry training: Insights from the shop floor. Paper presented to the New Zealand Association for Research in Education Conference, Palmerston North, December.

(2002). Final Report, NZ Dairy Workers Union: Membership Survey 2000. Hamilton: Centre for Labour and Trade Union Studies, Dept of Sociology and Social Policy, University of Waikato, $67 \mathrm{pp}+10$.

(2003a) Unions and social policy: Enhancing educational opportunities for workers. In Jorgensen, C.H. \& Warring, N. (eds). Adult Education and the Labour Market VII vol.A (933). Roskilde, Denmark: Roskilde University

(2003b) Bringing the state back in: New directions in trade union education in a small democracy. In Flowers, D. et al. (eds). Proceedings of the $44^{\text {th }}$ Adult Education Research Conference (235-240). San Francisco: San Francisco State University.

(2004). Social partnership: Rebuilding union capacity through education. In D. E. Clover (ed.). Adult education for democracy, social justice. and a culture of peace. Proceedings of the $45^{\text {th }}$ Adult Education Research Conference and the $25^{\text {th }}$ Conference of the Canadian Society for the Study of Adult Education. (322-327) Victoria, British.Columbia: University of Victoria

Law, M, \& Cochrane, W. (2004). Interim Report NZ Dairy Workers' Union Manufacturing Excellence
Survey 2003. Hamilton: Centre for Labour and Trade Union Studies, University of Waikato.

Law, M \& Piercy, G. (1999) Workplace democracy and training reform: Some emerging insights from Australia and New Zealand. In Salling Olesen, H. and Jackson, K. (eds), Adult Education and the Labour Market V. (63-86), Roskilde, Denmark: Roskilde University Press.

(2000a). Training and the new industrial relations: New Zealand research that explores Streeck's thesis. In Sork, T., Chapman, V. and St. Clair, R. (eds). AERC 2000: 41st Annual Adult Education Research Conference Proceedings. (235-240). Vancouver, Canada: University of British Columbia

(2000b). Unions and education and training reform: A neglected story. Paper presented to the New Zealand Association for Research in Education Conference, Hamilton, December, 2000.

(2000c) The Carmichael vision and training reform: Some insights from across the Tasman. In Burgess, J. and Strachan, G. (eds), Research on work, Employment and Industrial Relations 2000, Proceedings of the $14^{\text {th }}$ Association of Industrial Relations Academics Australia and New Zealand (AIRAANZ) Conference, Vol. 2, 141-150, Newcastle, NSW: University of Newcastle.

Lloyd, C. and Payne, J. (2002). Developing a political economy of skill. Journal of Education and Work 15(4), 365-390.

Maharey, S. (2001). Foreword. In Office of the Associate Minister of Education (Tertiary Education). Skills for a Knowledge Economy: A Review of Industry Training in New Zealand. Wellington: Author

McQueen, F. (2003). New Zealand's Employment Relations Policies and the Third Way. In Qualityassured Stream: Conference Proceedings of the 2003 Sociological Association of Aotearoa Conference: "Knowledge, Capitalism, Critique". (December, 2003: Auckland University of Technology University of Technology)

Ministry of Education (2002a). Tertiary Education Strategy 2002/07. Wellington: Author.

(2002b). Statement of Tertiary Education Priorities 2002/03. Wellington: Author.

(2003). Statement of Tertiary Education Priorities 2003/04. Wellington: Author.

(2003b). Statement of Tertiary Education Priorities 2003/04. Press Statement. Wellington: Author. 
New Zealand Council of Trade Unions (1992a). Building a Better Workplace. Wellington: Author.

(1992b). A Quality Future. Wellington: Author.

(1993a). Building Better Skills : Industry Training: Skills Formation to Take New Zealand into the 2Ist Century as a High Skill, High Wage Economy. Wellington: Author.

(1993b). A Policy for Quality Education. Wellington: Author.

(2002). Unions Innovation \& Sustainable Development. Wellington: Author.

(2003). Charters and Profiles. Wellington: Author.

New Zealand Labour Party (1999, 14 July). $2 I^{\text {st }}$ Century Skills: Building Skills for Jobs and Growth. Retrieved 24 April 2002, from http://www.liveupdater/com/labourparty/print.asp ?ArtID =-2069458396

New Zealand Qualifications Authority (1990) Towards a national qualifications framework: General principles and directions. Wellington: NZQA.

Office of the Associate Minister of Education (Tertiary Education). Skills for a Knowledge Economy: A Review of Industry Training in New Zealand. Wellington: Author

Parker, M. and Slaughter, J. (1988). Choosing Sides: Unions and the Team Concept. Detroit: Labor Notes

(1994). Working Smart: A Union Guide to Participation Programs and Reegineering. Detroit: Labor Notes.

Parkin, M. (2004). Manufacturing Excellence - NZITO Presentation, 2004 New Zealand Industry training Organisation Annual Conference. Auckland.

Perry, M., Davidson, C. and Hill, R. (1995). Reform at Work. Auckland: Longman Paul.

Piercy, G. (1999). Strategy and vision: The influence of the AMWU on the NZEU 1987-1992 with respect to education and training reforms. Unpublished MSocSc Thesis, University of Waikato, Hamilton, New Zealand.

(2003a). A 'third way' in industry training: New Zealand's adaptation of selected British policies. In Jorgensen, C.H. and Warring, N. (Eds.), Adult education and the labour market VII. Vol. A, (3562). Roskilde, Denmark: Roskilde University.

(2003b). Unions and the knowledge society. In Quality-assured Stream: Conference Proceedings of the 2003 Sociological Association of Aotearoa Conference: "Knowledge, Capitalism, Critique". (December, 2003): Auckland: Auckland University of Technology)

Reeves, W.P. (1902). State Experiments in Australia \& New Zealand. London: Grant Richards.

Schultz, T. (1961). Investment in human capital. American Economic Review 51, 1-17.

Sinclair, K. (1988). A History of New Zealand. Auckland: Penguin.

Stalker, J. (2000) The Third Way and feminist imaginings.. In Sork, T., Chapman, V. and St. Clair, R. (eds). AERC 2000: 41st Annual Adult Education Research Conference Proceedings. (438-442). Vancouver, Canada: University of British Columbia

Streeck, W. (1992). Training and the new industrial relations; a strategic role for unions? In Regini, M.(ed.), The Future of Union Movements. London: Sage.

Street, M. and Law, M. (1999) Employment related workers 'education and paid educational leave for a post-ECA environment. Paper presented to NZ Council of Trade Unions Biennial Conference, Wellington

Tertiary Education Advisory Commission (2001). Shaping the Funding Framework. Wellington: Author.

Voos \& Kim (2001) High performance work systems in the U.S. context. Transfer 7(3), 422-440. 